\author{
В.В. Мегельбей, О.В. Лезік, В.Ю. Бабич, Д.С. Роменський \\ Харківський національний університет Повітряних Сил ім. І. Кожедуба, Харків
}

\title{
МЕТОДИКА ОЦІНЮВАННЯ ЖИВУЧОСТІ ОЗБРОЄННЯ ЗЕНІТНОГО ПІДРОЗДІЛУ (ЧАСТИНИ)
}

\begin{abstract}
В статті акцентовано увагу на вирішенні завдання оцінювання жсиучості озброєння зенітного підрозділу (частини) в ході ведення оборонних дій. Показано шляхи рішення цьього завдання за рахунок використання методики, яка враховує чинники, щьо впливають на живучість систем і комплексів зенітного озброєння. Запропонована методика оцінювання живучості зенітного озброєння враховує динаміку сучасного бою, різні варіанти нанесення ударів противником та вплив можливих заходів щзодо підвищення живучості на ії рівень, щзо дає можливість провести порівняльний аналіз пропозицій щзоо забезпечення необхідного рівня живучості зенітного озброєння в штабах (органах військового управління) в ході планування та ведення бойових дій.
\end{abstract}

Ключові слова: живучість, методика очінювання, озброєння, система протиповітряної оборони.

\section{Вступ}

Постановка проблеми. Під час розробки i проектування зенітного ракетного комплексу (ЗРК) висуваються ряд вимог до його рівня живучості в прогнозованих умовах ведення бойових дій. Зважаючи на те, що ЗРК, що знаходяться на озброєнні зенітних підрозділів (частин) військ протиповітряної оборони Сухопутних військ (ППО СВ), проектувалися напочатку та в середині минулого століття, відповідно, в них реалізовані певні технічні рішення щодо забезпечення живучості під час авіаційних ударів повітряного противника. Забезпечення живучості цих ЗРК досягається традиційними методами дублювання, резервування, бронювання і взаємного екранування основних вузлів і блоків ЗРК. Однак, як показує досвід локальних війн і військових конфліктів кінця XX - початку XXI століття, традиційні методи і засоби підвищення живучості ЗРК в умовах застосування противником високоточної зброї (ВТ3), безпілотних літальних апаратів (БпЛА), підвищення точності й швидкодії артилерії не можуть забезпечити необхідний рівень живучості зенітного озброєння частин і підрозділів військ ППО СВ. Отже, виникає актуальне завдання розробки науково обгрунтованих пропозицій щодо підвищення живучості озброєння зенітного підрозділу (частини) військ ППО СВ в сучасних умовах ведення бойових дій за рахунок певних організаційно-тактичних заходів. 3 метою розробки обгрунтованих пропозицій та порівняння прийнятих рішень щодо підвищення живучості озброєння зенітного підрозділу (частини) необхідна модель, яка б характеризувала його живучість на протязі певного відрізку часу. Ця модель $є$ основою для розробки методики оцінювання живу- чості. Час, за який оцінюється живучість озброєння зенітного підрозділу (частини) доцільно обирати в межах $0 \leq t \leq t_{c p}$, де $t_{c p}$ - середній час перебування озброєння зенітного підрозділу на позиціях.

Аналіз останніх досліджень і публікацій. Аналіз останніх публікацій щодо проблеми живучості свідчить що дослідження в цьому напрямку не припиняються.

В роботах [1-3] основна увага приділяється визначенню можливостей противника щодо викриття систем озброєння засобами розвідки і безпосереднього їх вогневого ураження, при цьому в запропонованих методиках недостатньо враховується дія чинників що впливають на рівень живучості щодо та фактор часу.

Ряд робіт [4-6] присвячені розробці методик оцінюванню живучості засобів протиповітряної оборони з урахуванням часу ведення бойових дій, спираючись на метод моделювання за схемою марковських випадкових процесів. Даний підхід може дати досить точні оцінки живучості в ході наукових досліджень але, разом $з$ тим, його використання в штабах (органах військового управління) під час підготовки і ведення бойових дій (операцій) може призвести до значних витрат часу на проведення розрахунків у відповідних посадових осіб.

В роботі [7] запропонована досить проста аналітична методика для оцінювання живучості ЗРК в ході ведення бойових дій, в якій враховуються фактор часу та вплив заходів з підвищення живучості на iii рівень. Основна увага приділяється оцінюванню живучості ЗРК під час нанесення повітряних ударів пілотованої авіації противника та артилерійськими системами. В враховуючи реалії сьогодення, в даній 
методиці потребують уточнення деяких положень щодо визначення імовірності ураження ЗРК вогнем артилерії $з$ корегуванням вогню за допомогою безпілотних літальних апаратів.

Робота [8] дещо розширює і уточнює методику, викладену в роботі [7], але їі положення необхідно доопрацювати з урахуванням характеристик ЗРК та можливістю застосування противником ударних БПЛА для знищення (подавлення) ЗРК.

Мета статті - розробка методики оцінювання живучості озброєння зенітного підрозділу (частини) в ході ведення бойових дій в сучасних умовах.

\section{Виклад основного матеріалу}

При аналізі чинників, які впливають живучість зенітного озброєння та розробці обгрунтованих пропозицій щодо іiі підвищення будемо спиратися на методику оцінювання живучості сил і засобів ППО, запропоновану в роботі [8]. Як відомо [9], живучість характеризується можливостями комплексу (системи) озброєння зберігати або швидко відновляти свою боєздатність в умовах застосування противником різних засобів ураження. В якості показника ступеню збереження боєздатності озброєння зенітного підрозділу можливо використовувати імовірність не ураження його вогнем противника за час $t$ [7]:

$$
P(t)=\left(1-P_{u}\right)^{\frac{t}{t_{u}}},
$$

де $t_{u}$ - тривалість циклу “розвідка-ураження” засобу вогневого ураження противника;

$P_{u}$ - імовірність ураження елементів системи управління за час $t_{u}$.

3 метою визначення величин $t_{u}$ та $P_{u}$ розглянимо основні можливі моделі удару противника по озброєнню зенітного підрозділу (частини).

Перша модель - удар наноситься авіацією. В цьому випадку за час циклу “розвідка-ураження” $t_{u 1}$ противник має провести розвідку цілей, підготовку і передачу даних про виявлені цілі (цілевказівка), прийняття рішення на застосування авіації, здійснити політ авіації в район цілі, здійснити безпосереднє виявлення визначених цілей і нанести удар. В такому випадку час $t_{u}$ можна представити у вигляді суми відповідних проміжків часу:

$$
t_{u 1}=t_{p}+t_{Ц B}+t_{n}+t_{y},
$$

де $t_{p}$ - час необхідний для виявлення цілей (елементів системи управління) з заданою імовірністю для нанесення удару;

$t_{Ц B}$ - час на підготовку та передачу цілевказівки; $t_{n}$ - час підготовки та польоту авіації в район виявлених цілей;

$t_{y}$ - час безпосереднього пошуку (допошуку) цілей в заданому районі і нанесення ударів по ним.

Друга модель - удар наноситься розвідувальноударним (розвідувально-вогневим) комплексом (РУК (РВК)), артилерійським вогнем. У такому випадку за час $t_{p}$ здійснюється розвідка цілей, як правило, за допомогою безпілотних літальних апаратів (БпЛА), за час $t_{Ц в}$ передача даних цілевказівки, за час $t_{\text {nid }}$ здійснюється підготовка даних для ведення вогню (пуску ракет) та за час $t_{y}$ здійснюється нанесення удару (політ ракет або снарядів до цілей). Отже, тривалість циклу “розвідка-ураження” для другої моделі складає:

$$
t_{u 2}=t_{p}+t_{Ц B}+t_{n i \partial}+t_{y} .
$$

Третя модель - удар наноситься за допомогою ударних БПЛА. За таких умов за час $t_{p}$ здійснюється розвідка (пошук) цілей для ураження, за час $t_{\text {niд }}$ здійснюється підготовка даних та прийняття рішення на ведення вогню (пуску ракет) та за час $t_{y}$ здійснюється нанесення удару (політ ракет або снарядів до цілей). Отже, тривалість циклу “розвідкаураження" для третьої моделі складає:

$$
t_{u 3}=t_{p}+t_{n i d}+t_{y} .
$$

Аналіз складових циклу “розвідка-ураження” першої, другої і третьої моделей удару противника показує, що за інших рівних умов час підготовки і польоту авіації в район виявлених цілей $\left(t_{n}\right)$ та час нанесення удару по цілям $\left(t_{y}\right)$ для першої моделі перевищують відповідні часові інтервали $\left(t_{\text {nid }}\right.$ i $\left.t_{y}\right)$ другої моделі, а витрати часу для третьої моделі менші від другої, як мінімум через відсутність часових витрат на передачу даних для цілевказівки та скорочення часу для підготовки даних для ведення вогню (нанесенню удару). Відповідно, можна вважати, що $t_{u 1} \gg t_{u 2} \gg t_{u 3}$.

Зважаючи на те, що озброєння зенітних підрозділів (частин) військ ППО СВ розгортається, як правило, в районах, які знаходяться в межах досяжності РУК (РВК) противника, доцільно вважати, що друга модель нанесення удару буде більш пріоритетною під час прийняття рішення противником на вогневе ураження у порівнянні з першою.

Туреччина продемонструвала у війні в Сирії та бойовими діями між Азербайджаном та Вірменією зрілість концепції бойового застосування ударних безпілотних авіаційних комплексів. Безпілотники виявилися дуже ефективним елементом сучасної 
війни, особливо на початковій іiі фазі, під час придушення системи ППО та завоювання переваги у повітрі. Тому, цілком припустимо, що у майбутніх бойових діях ударні БпЛА будуть одними з основних засобів знищення (придушення) озброєння зенітних підрозділів (частин) військ ППО СВ [4; 12].

Розглянемо імовірність ураження озброєння зенітного підрозділу (частини) за час $t_{u}$. Для прийнятих моделей значення $P_{u}$ може бути визначене як добуток імовірностей [7]:

$$
P_{u}=\left\{\begin{array}{l}
P_{\theta} P_{M} P_{\text {РЦв }} P_{y p}, \text { для I моделі; } \\
P_{\theta} P_{M} P_{y p}, \quad \text { для II та III моделей, }
\end{array}\right.
$$

де $P_{b}$ - імовірність виявлення озброєння противником за цикл пошуку (при первинному пошуку);

$P_{M}$ - імовірність невиходу (не здійснення маневру) зенітного підрозділу з-під удару противника;

$P_{Р Ц в}$ - імовірність виявлення озброєння зенітного підрозділу авіацією противника в заданому районі при безпосередньому пошуку (допошуку) (імовірність реалізації цілевказівки);

$P_{y p}$ - імовірність ураження озброєння вогневими засобами противника.

Для оцінки величин $P_{6}$ i $P_{P Ц в}$ скористаємося виразом [7]:

$$
P=\frac{\left(1-K_{M}\right) \mathrm{W}}{1-\xi^{\eta}},
$$

де $K_{M}$ - ступінь маскування озброєння від різних видів розвідки противника;

$W$ - імовірність виявлення озброєння противником за цикл розвідки;

$\eta$ - кількість хибних позицій озброєння зенітного підрозділу, що припадають на одну реальну;

$\xi$ - ступінь правдоподібності хибних позицій.

Значення імовірності невиходу (не здійснення маневру) зенітного підрозділу з-під удару противника може бути визначене за формулами [7]:

$$
P_{\mathcal{M}}=\left\{\begin{array}{l}
1-\frac{t}{t_{c p}}, \quad \text { при } t<t_{p}+t_{3} ; \\
\frac{t-t_{p}-t_{3}}{t_{c p}} e^{\frac{t-t_{p}-t_{3}}{t_{c p}-t_{p}-t_{3}}}, \quad \text { при } t \geq t_{p}+t_{3},
\end{array}\right.
$$

де $t$ - час від моменту виявлення озброєння зенітного підрозділу до нанесення по ним удару;

$t_{c p}$ - середній час перебування зенітного підрозділу на позиціях;

$t_{p}$ - час розгортання зенітного підрозділу;

$t_{3}$ - час згортання зенітного підрозділу.

Імовірність ураження озброєння зенітного підрозділу засобами противника в загальному випадку визначається залежністю [9]:

$$
P_{y p}(n)=\sum_{m=0}^{n} R_{n, m} G(m),
$$

де $R_{n, m}$ - імовірність влучання в ціль рівно $m$ пострілами (пусками) при $n$ пострілах;

$G(m)$ - закон ураження цілі.

На озброєнні зенітних підрозділів (частин) військ ППО СВ, в основному, знаходяться ЗРК, які мають броню, що захищає від осколків та куль. Зважаючи на це, будемо рахувати, що всі сучасні авіаційні засоби ураження, засоби ураження реактивної та ствольної артилерії по відношенню до ЗРК мають надлишкову потужність руйнівної дії і для ураження ЗРК достатньо $k$ влучань засобів ураження. В такому випадку закон ураження цілі може бути представлений у вигляді ступінчатого закону ураження [9]:

$$
G(m)=\left\{\begin{array}{l}
0, \text { при } m=0 ; \\
1, \text { при } m \geq k .
\end{array}\right.
$$

Для ступінчатого закону ураження імовірність ураження цілі дорівнюватиме імовірності не менше $k$ влучань в ціль:

$$
P_{y p}(\mathrm{n})=R_{n, k} .
$$

Коли постріли незалежні один від одного значення $R_{n, k}$ можна обчислити за формулою [9]:

$$
R_{n, \mathrm{k}}=P(m \geq k)=\sum_{m=k}^{n} C_{n}^{m} p^{m}(1-p)^{n-m},
$$

де $p$-імовірність влучання в ціль при одному пострілі.

Для першої та третьої моделей, як правило, характерне прицілювання по конкретному об'єкту (наприклад, бойова машина) [11]. В такому випадку для приблизних розрахунків можна прийняти імовірність влучання в ціль як імовірність влучання в коло з радіусом $r$ і центром розсіювання, що співпадає $з$ центром кола [3; 7]:

$$
p=1-e^{\frac{r^{2}\left(1-K_{\text {інж) }}\right)}{2 \sigma^{2}}},
$$

де $r$-радіус кола, в яке необхідно влучити, як правило, дорівнює радіусу ураження боєприпасу;

$K_{\text {інж }}$ - коефіцієнт, що враховує інженерне обладнання позицій;

$\sigma$-середньоквадратичне відхилення боєприпасу.

Друга модель, як правило, передбачає ураження певної площі. При рівномірному розподілу влучань по площі елементу системи управління імовірність його ураження може бути приблизно оцінена за виразом [3; 7]:

$$
P_{y p}(n) \approx 1-e^{-n \mu}
$$

де $\mu$ - математичне очікування долі ураженої площі 
цілі при одному пострілі, яка обчислюється за формулою:

$$
\mu=\frac{\bar{S}_{y p}}{S_{u}},
$$

де $\bar{S}_{y p}$ - математичне очікування ураженої площі цілі при одному влучанні;

$$
S_{u} \text { - площа цілі. }
$$

При обчисленні математичного очікування ураженої площі при одному влучанні будемо вважати, що площа озброєння зенітного підрозділу (або його складової частини) апроксимується рівновели- ким прямокутником зі сторонами $\bigsqcup_{x}$ і $\bigsqcup_{y}$. Зона ураження при влучанні замінюється рівновеликим прямокутником із сторонами $L_{x}$ i $L_{y}$. Напрямки координатних осей вибираються паралельно головним осям еліпса розсіювання точок влучання [3].

Як правило, зона ураження одного пострілу апроксимується колом з радіусом $r$. В такому випадку $L_{x}=L_{y}=r \sqrt{\pi}=1,772 r$.

За таких припущень математичне очікування ураженої площі при одному пострілі знаходиться за формулою [3]:

$$
\begin{aligned}
\bar{S}_{y p}= & \frac{E_{x} E_{y}}{4}\left[\hat{\phi}\left(\frac{x_{2}+\bar{x}}{E_{x}}\right)+\hat{\phi}\left(\frac{x_{2}-\bar{x}}{E_{x}}\right)-\hat{\phi}\left(\frac{x_{1}+\bar{x}}{E_{x}}\right)-\hat{\phi}\left(\frac{x_{1}-\bar{x}}{E_{x}}\right)\right] \times \\
& \times\left[\hat{\phi}\left(\frac{y_{2}+\bar{y}}{E_{y}}\right)+\hat{\phi}\left(\frac{y_{2}-\bar{y}}{E_{y}}\right)-\hat{\phi}\left(\frac{y_{1}+\bar{y}}{E_{y}}\right)-\hat{\phi}\left(\frac{y_{1}-\bar{y}}{E_{y}}\right)\right],
\end{aligned}
$$

$$
\begin{aligned}
\text { де } x_{1}=\frac{\bigsqcup_{x}-L_{x}}{2} ; x_{2}=\frac{\bigsqcup_{x}+L_{x}}{2} ; y_{1}=\frac{Ц_{y}-L_{y}}{2} ; \\
y_{1}=\frac{\bigsqcup_{y}+L_{y}}{2} ; \quad E_{x}, E_{y}-\text { серединні відхилення }
\end{aligned}
$$

точок влучання боєприпасу;

$\bar{x}, \bar{y}$ - координати точок прицілювання;

$\hat{\phi}(z)$ - інтеграл від приведеної функції Лаплаca $\hat{\Phi}(z)$.

Таким чином, всі необхідні величини, які необхідні для визначення імовірності не ураження озброєння зенітного підрозділу (частини) вогнем противника за час $t$ знайдені.

Отже, використовуючи запропоновану модель, методика оцінювання живучості озброєння зенітного підрозділу (частини) в ході ведення оборонних дій може викладена наступним чином.

В ході оцінювання противника відповідні командири (начальники) визначають можливості противника щодо вогневого ураження позиційних районів (позицій) своїх зенітних підрозділів різними видами зброї. Під час проведення аналізу доцільно визначити пріоритети для запропонованих моделей ударів. Виходячи із конкретних умов обстановки i наявних відомостей про противника визначаються сили і засоби розвідки противника, що діють у визначеній полосі, імовірність виявлення озброєння зенітного підрозділу противником за цикл розвідки, можливий наряд сил і засобів для нанесення авіаційного, ракетного ударів та веденню артилерійського вогню по зенітним підрозділам.

Для визначених систем озброєння, що імовірно можуть застосовуватися для придушення (знищення) озброєння зенітного підрозділу проводяться розрахунки імовірності влучання в ціль при одному пострілі за виразами (12-13) для відповідної моделі удару та визначаються імовірності ураження озброєння зенітного підрозділу засобами противника за виразами $(11 ; 9 ; 8)$.

Під час оцінювання своїх військ відповідні командири (начальники) визначають можливості підлеглих зенітних підрозділів щодо здійснення маскування, інженерного обладнання позицій, обладнання хибних позицій, з'ясовують які сили і засоби інженерного забезпечення старшого начальника виділяються в інтересах своїх підрозділів. Результатом аналізу мають стати відомості щодо можливого ступеню маскування озброєння зенітного підрозділу від різних видів розвідки противника, можливостей щодо обладнання хибних позицій та їх правдоподібності. За отриманими даними розраховуються імовірності виявлення озброєння противником за цикл пошуку за виразом (6).

В ході оцінювання місцевості, де передбачається ведення бойових дій, командири (начальники) проводять аналіз впливу умов місцевості на маневрені можливості зенітних підрозділів та корегують відповідні часові показники у виразі (7) та здійснюють розрахунок імовірності невиходу (не здійснення маневру) зенітного підрозділу з-під удару противника.

Отримавши значення імовірностей виявлення озброєння зенітного підрозділу противником за цикл пошуку (при первинному пошуку) та авіацією противника в заданому районі при безпосередньому пошуку (допошуку) (імовірність реалізації цілевказівки), невиходу (не здійснення маневру) зенітного підрозділу з-під удару противника й імовірність ураження озброєння зенітного підрозділу вогневими засобами противника розраховується імовірність ураження озброєння зенітного підрозділу (частини) 
за час $t_{u}$ (вираз (5)) та проводиться оцінка прийнятого показника живучості озброєння зенітного підрозділу за середній час перебування озброєння зенітного підрозділу на позиціях. Отриманий результат аналізується та, за необхідності, розробляються пропозиції щодо підвищення рівня живучості шляхом зменшення середнього часу перебування підрозділів на позиціях, покращення маскування i iнженерного обладнання позицій та проведення інших заходів щодо введення противника в оману.

\section{Висновки}

Отже, запропонована модель оцінки живучості озброєння зенітного підрозділу враховує чинники які впливають на рівень іiі живучості, визначає залежність рівня живучості від часу та враховує особливості обчислення імовірностей ураження озброєння для запропонованих моделей ударів.

На основі даної моделі запропонована методи ка оцінювання живучості озброєння зенітного підрозділу (частини), яка органічно поєднується 3 про- цедурами етапу організації планування бойових дій. Наведена методика дозволяє аналітичним способом провести оцінювання живучості озброєння зенітного підрозділу (частини) та розробити, у разі необхідності, обгрунтовані пропозиції щодо підвищення рівня живучості.

При розробці пропозицій щодо підвищення живучості озброєння зенітного підрозділу (частини) в сучасних бойових діях слід зосереджувати увагу на впровадженні організаційно-технічних заходів спрямованих на:

- збільшення часу і зменшення імовірності виявлення противником ЗРК;

- збільшення часу безпосереднього пошуку цілей для нанесення удару авіацією противника в районах розгортання ЗРК;

- зменшення імовірності ураження ЗРК в результаті нанесення ударів противником;

- зменшенні середнього часу перебування озброєння на позиціях.

\section{Список літератури}

1. Мильграм Ю.Г. Боевая эффективность авиационной техники и исследование операций / Ю.Г. Мильграм, И.С. Попов. - М.: ВВИА им. Н.Е. Жуковского, 1970. - 500 с.

2. Вероятностные методы оценки эффективности вооружения / А.А. Червоный, В.А. Шварц, А.П. Козловцев, В.А. Чобанян; под ред. проф. А.А. Червоного. - М.: Воениздат, 1979. - 95 с.

3. Абчук В.А. Справочник по исследованию операций / В.А. Абчук, Ф.А. Матвейчук, Л.П. Томашевский; под общ. ред. Ф.А. Матвейчука. - М.: Воениздат, 1979. - 368 с.

4. Загорка О.М. Методичні положення оцінки живучості зенітної ракетної системи від дії по її елементах засобів ураження противника / О.М. Загорка, В.В. Коваль, І.О. Загорка // Збірник наукових праць Харківського національного університету Повітряних Сил. - 2017. - № 4. - С. 12-16.

5. Гогонянц С.Ю. Основні положення удосконаленої методики оцінки живучості угруповання зенітних ракетних військ при виконанні завдань зенітного ракетного прикриття / С.Ю. Гогонянц, Г.С. Степанов // Системи озброєння і військова техніка. - 2012. - № 2. - С. 37-41.

6. Титаренко О.Б. Окремі положення удосконаленої методики оцінки живучості угруповання зенітних ракетних військ при відбитті удару засобів повітряного нападу противника / О.Б. Титаренко, С.Ю. Гогонянц // Наука і техніка Повітряних Сил Збройних Сил України. - 2015. - № 1. - С. 45-48.

7. Оленович И.Ф. Система противовоздушной обороны Сухопутных войск и оценка ее эффективности / И.Ф. Оленович, В.Д. Кохно, О.В. Зайцев. - К.: ВА ПВО СВ, 1988. - 117 с.

8. Методика оцінювання живучості системи управління вогнем зенітного підрозділу (частини) / В.В. Мегельбей, С.О. Кравченко, Д.С. Іщенко та ін. // Збірник наукових праць Державного науково-дослідного інституту озброєння та військової техніки. - 2020. - № 1. - С. 77-83.

9. Довідник з протиповітряної оборони / А.Я. Торопчин, I.О. Романенко, Ю.Г. Даник, Р.Е. Пащенко та ін. - К.: МО України, Х.: ХВУ, 2003. - 368 с.

10. Вентцель Е.С. Введение в исследование операций / Е.С. Вентцель. - М.: Советское радио, 1964. - 389 с.

11. Полуйко О.М. Вибір точок прицілювання по елементарним цілям складного (групового) об'єкту / О.М. Полуйко, П.М. Онипченко // Системи озброєння і військова техніка. - 2017. - № 2(50). - С. 22-25.

12. Аналіз застосування БПЛА у вірмено-азербайджанському воєнному конфлікті та можливі шляхи боротьби 3 ними / А.Ф. Волков, О.В. Лезік, С.І. Корсунов, Г.А. Левагін, О.В. Яновський, К.В. Івахненко // Системи озброєння і військова техніка. - 2020. - № 4(64). - С. 7-17. https://doi.org/10.30748/soivt.2020.64.01.

Надійшла до редколегії 22.01.2021 Схвалено до друку 02.03.2021

\section{Відомості про авторів:}

\section{Мегельбей В'ячеслав Вікторович}

кандидат технічних наук начальник науково-дослідної лабораторії Харківського національного університету Повітряних Сил ім. І. Кожедуба,

Харків, Україна

https://orcid.org/0000-0001-7785-765X

\section{Information about the authors:}

Viacheslav Mehelbei

Candidate of Technical Sciences Chief of Research Laboratory of Ivan Kozhedub Kharkiv National

Air Force University,

Kharkiv, Ukraine

https://orcid.org/0000-0001-7785-765X 


\section{Лезік Олександр Віталійович}

кандидат військових наук доцент доцент кафедри Харківського національного університету Повітряних Сил ім. I. Кожедуба,

Харків, Україна

https://orcid.org/0000-0002-7186-6683

Бабич Володимир Юрійович

курсант Харківського національного університету Повітряних Сил ім. І. Кожедуба,

Харків, Україна

https://orcid.org/0000-0002-6849-2588

Роменський Денис Сергійович

курсант Харківського національного університету Повітряних Сил ім. І. Кожедуба,

Харків, Україна

https://orcid.org/0000-0002-2789-7968

\section{Oleksandr Lezik}

Candidate of Military Sciences Associate Professor

Senior Lecturer of Ivan Kozhedub Kharkiv National

Air Force University,

Kharkiv, Ukraine

https://orcid.org/0000-0002-7186-6683

Volodymyr Babych

Cadet of Ivan Kozhedub Kharkiv National

Air Force University,

Kharkiv, Ukraine

https://orcid.org/0000-0002-6849-2588

Denis Romenskyi

Cadet of Ivan Kozhedub Kharkiv National

Air Force University,

Kharkiv, Ukraine

https://orcid.org/0000-0002-2789-7968

\section{МЕТОДИКА ОЦЕНКИ ЖИВУЧЕСТИ СИСТЕМЫ УПРАВЛІННЯ ОГНЕМ ЗЕНИТНОГО ПОДРАЗДЕЛЕНИЯ (ЧАСТИ)}

В.В. Мегельбей, А.В. Лезик, В.Ю. Бабич, Д.С. Роменський

В статье акиентировано внимание на решении задачи оценки живучести зенитно-ракетного комплекса. Показаны пути решения этой задачи за счет использования определенных методик, с помощью которых можно провести анализ факторов, влияющих на живучесть зенитно-ракетного комплекса. Оиенка живучести зенитно-ракетного комплекса осуществляется на основе модели, которая характеризует живучесть зенитно-ракетного комплекса на определенном отрезке времени. Время, за которое оценивается живучесть зенитно-ракетного комплекса целесообразно в пределах среднего времени нахождения зенитно-ракетного комплекса на своих позициях. В качестве показателя живучести принята вероятность не поражения зенитно-ракетного комплекса огнем противника на принятом отрезке времени. Принятый показатель характеризуется рядом частных показателей: вероятностью обнаружения (вероятностью непосредственного обнаружения авиацией противника в заданном районе) зенитно-ракетного комплекса; вероятностью невыхода элементов системь управления из-под удара противника; вероятностью поражения зенитноракетного комплекса средствами противника. В свою очередь, частные показатели учитывают возможности противника по обнаружению и нанесению ударов по зенитно-ракетным комплексам зенитного подразделения (части), а также возможное влияние проводимых организационно-технических мероприятий, направленных на улучшение маскировки, создание ложных позиций, инженерного обеспечения на снижение вероятности обнаружения и поражения элементов системы управления огнем зенитного подразделения (части). Предложенная методика оценки живучести зенитно-ракетного комплекса, учитывающая динамику ее функционирования, влияние возможных мероприятий по повышению живучести на ее уровень, учитывает различные варианты нанесения ударов противником и дает возможность провести сравнительный анализ предложений по обеспечению необходимого уровня живучести системы в штабах (органах военного управления) в ходе планирования и ведения боевых действий.

Ключевые слова: живучесть, методика оценки, система управления огнем, система противовоздушной обороны.

\section{METHODOLOGY OF ASSESSMENT OF FIRE CONTROL SYSTEM SURVIVABILITY OF ANTIAIRCRAFT SUB-UNIT (ANTI-AIRCRAFT UNIT)}

\section{Mehelbei, O. Lezik, V. Babych, D. Romenskyi}

The article focuses on solving the problem of assessing the survivability of a anti-aircraft missile system. The ways of solving this problem are shown by the use of certain methods, by which it is possible to carry out the analysis of the factors that influence the survivability of the anti-aircraft missile system. Assessment of the survivability of the anti-aircraft missile system is carried out on the basis of a model that characterizes the survivability of the system for a certain period of time. The time for which the survivability of the system is estimated is advisable within the average time spent by the elements of the control system in their positions. As an indicator of survivability, the probability of non-defeat of elements of the enemy anti-aircraft missile system over the adopted period of time is accepted. The adopted indicator is characterized by a number of particular indicators: the probability of detection (the probability of direct detection by enemy aircraft in a given area) of the control system elements; the probability of absenteeism of control elements from under the attack of the enemy; the probability of defeat of the elements of the enemy assets management system In turn, private indicators take into account the enemy's ability to detect and strike at elements of the fire control system of an anti-aircraft sub-unit (anti-aircraft unit), as well as the possible impact of organizational and technical measures aimed at improving camouflage, creating false positions, and engineering support to reduce the likelihood of detection and defeat of elements of a fire control system of an anti-aircraft sub-unit (anti-aircraft unit). The proposed methodology for assessing the survivability of a fire control system takes into account the dynamics of its operation, the impact of possible measures to increase survivability at its level, takes into account different options for striking the enemy and allows a comparative analysis of proposals to ensure the required level of survivability of the system in the headquarters (military authorities) planning and conducting combat operations.

Keywords: survivability, evaluation technique, fire control system, air defense system. 